\title{
Microbiological Studies of Aquatic Habitats of the Area of Inuvik, Northwest Territories ${ }^{1}$
}

\author{
WILLIAM L. BOYD ${ }^{2}$ AND JOSEPHINE W. BOYD
}

\begin{abstract}
Chemical and microbiological studies were carried out on lakes, ponds, and the Mackenzie River in the vicinity of Inuvik. With a few exceptions the chemical composition of most of the bodies of water was uniform throughout the ice-free period. The number of psychrophilic and mesophilic bacteria increased in all cases but not necessarily at the same time; the counts of thermophilic bacteria and molds were low. Ancillary studies were also carried out on runoff water and the town's water distribution and sewage disposal systems.

RÉSUMÉ. Études microbiologiques d'habitats aquatiques de la région d'Inuvik, T.N.-O. Les auteurs ont mené des études chimiques et microbiologiques dans des lacs et des mares et sur le fleuve Mackenzie, au voisinage d'Inuvik. Sauf pour quelques exceptions, la composition chimique de la plupart de ces eaux était uniforme tout au long de la période pendant laquelle elles étaient libres de glace. Dans tous les cas, le nombre de bactéries psychrophiles et mésophiles augmentait, mais pas nécessairement au même moment; les comptages de bactéries thermophiles et de moisissures donnèrent des chiffres assez bas. Des études auxiliaires furent aussi menées sur l'eau de ruissellement et sur les réseaux d'adduction d'eau et d'égouts de la ville.
\end{abstract}

РЕЗЮМЕ. Микробиологические исследования водных обиталищ в районе Инувик, Сев.-Зап. Территории, Канада. Производились химические и микробиологиъеские исследования озер, прудов и рекп. Макензи кокрестностях Инувик. За некоторыми исключениями, химический состав большинства әтих вод был однороден в течение свободного ото льда периода. Число психрофильных и мезофильных бактерий возрастало во всех случаях, но не всегда в то же самое время ; число термофильных бактерий и плесени было низкое. Дополнительно исследовались воды стока, водоснабжения и канализации.

\section{INTRODUCTION}

For many years the main settlement in northwestern Canada was Aklavik, founded in I 912 as a small fur-trading post. In I919, an Anglican Mission was established followed by a Royal Canadian Mounted Police detachment in 1922, a signal station of the Royal Canadian Corps of Signals in 1925, and a Catholic Mission and Hudson Bay Company post in 1926; these formed the nucleus of the town which had grown to a population of about 400 in I 93 I and had exceeded 2,000 by 1957 . The town became the centre for the military and civilian governmental agencies concerned with the administration of this vast northern area (Baird I96o; Merrill et al. I960; Pihlainen I 962; MacKay I963).

Aklavik is located on the left side or western channel of the Mackenzie River (Peel Channel). The town is underlain with permafrost; the active layer of soil is high in organic matter, while the permafrost below consists of about 60 per cent in volume of ice. This condition complicated construc-

\footnotetext{
${ }^{1}$ These studies were aided by a contract between the Office of Naval Research, Department of the Navy, and the Arctic Institute of North America.

${ }^{2}$ Department of Microbiology, Colorado State University, Fort Collins, Colorado 8052 I.
} 
tion of large buildings; the stripping off of muskeg for their construction would have resulted in ground subsidence or cave-ins. Also, Aklavik is located on a flood plain about 2 I feet above sea level. Erosion and flooding were yearly problems plaguing the residents during the spring break-up which further reduced the area available for expansion. As general activity increased in this region in early I 953, it became necessary either to expand governmental facilities or to move them to another site. The latter plan was adopted, and in I 954 survey teams were sent out to look for a new site. Finally selected was an area 35 miles east of Aklavik, temporarily named East Three. Later the name was changed to Inuvik, Eskimo for 'Place of man'.

Inuvik is located at latitude $68^{\circ} 2 \mathrm{I}^{\prime} \mathrm{N}$., longitude $\mathrm{I} 33^{\circ} 44^{\prime} \mathrm{W}$., on the East Channel of the Mackenzie River, 75 miles south of the Beaufort Sea, and I 20 miles north of the Arctic Circle. Although it is in the geographic Arctic, it is well below the tree line and is more appropriately classified as subarctic. Spruce and birch are the dominating trees, but there are secondary stands of alder and willow. The ground consists of hummocks of peat usually covered by ground birch, reindeer and sphagnum mosses, grass tussocks, Labrador tea, and various berry plants (Pihlainen i 962).

Because of the large delta, the climate is mild compared with other areas of Canada and of Alaska at the same latitude. Based on three years of observations (Brown I960), the mean ground temperature has been shown to be $-3.4^{\circ} \mathrm{C}$. $\left(25.9^{\circ} \mathrm{F}\right.$.) with a mean annual air temperature of $-8.9^{\circ} \mathrm{C}$. $\left(16^{\circ} \mathrm{F}\right.$.). The entire area is underlain with continuous permafrost.

In planning the new town, a great deal of thought and effort went into the design of living, storage, and administrative units. The end result has been a modern town designed for living above the Arctic Circle, with all conveniences such as central heating, running water, modern bathrooms, electric lights, as well as a local CBC radio station (CHAK), hotel, churches, restaurant, liquor store, general store, laundry-dry cleaning establishment, a theatre, and an all-weather airport with scheduled air service to points both to the north and to the south. A great deal of specialized maintenance is required to keep the necessary services operational. The town itself is unique in the North American Arctic or Subarctic and represents a departure from the past practice of trying to adapt the construction techniques carried out in temperate regions. Instead, buildings and other structures were designed specifically for erection in northern regions underlain with permafrost. Houses and other buildings have been built on pilings similar to those used to support the modules of the Distant Early Warning (DEW) line sites - that is, the pilings are first frozen into the permafrost and are then maintained without disturbing the permafrost below. The town serves as a model city for further study in an attempt better to understand the environmental, psychological, and logistical problems associated with living in the Far North.

When they arrived in the summer of 1964 the authors were among the first resident research groups based at the then recently completed Inuvik 
Research Laboratory, which was operated by the Department of Northern Affairs and National Resources. A study of the bacteriological and chemical properties of most of the bodies of water in the immediate area was carried out in an attempt to learn about some of the area's unique water supply and distribution problems and how these problems differed from those of lower latitudes as well as other arctic and subarctic areas.

\section{MATERIALS AND METHODS}

All samples were collected at the water's surface in duplicate in sterile glass containers, the exception being the Mackenzie River where four samples were collected at four different stations. Potability tests were performed on five $10 \mathrm{ml}$. portions of each sample using standard methods (American Public Health Association, A.P.H.A. r 960). Dilutions were prepared from each sample and plated in triplicate on nutrient agar (Difco) and incubated at $37^{\circ} \mathrm{C}$. and at $55^{\circ} \mathrm{C}$. for 24 hours, at $22^{\circ} \mathrm{C}$. for 5 days, and at $2{ }^{\circ} \mathrm{C}$. for 14 days. Samples incubated at $55^{\circ} \mathrm{C}$. were used for the enumeration of thermophilic bacteria, those at $37^{\circ} \mathrm{C}$. and $22^{\circ} \mathrm{C}$. for mesophilic forms, and those at $2^{\circ} \mathrm{C}$. for psychrophilic microbes. Thornton's standardized medium, a chemically defined medium, was also used for the enumeration of bacteria (Allen 195I). Sabouraud's dextrose agar was used for the cultivation of molds. Selected chemical tests were carried out using Nalco equipment and standard prepared reagents (National Aluminate Company, Chicago, Illinois). The general methods have been reported by Boyd and Boyd ( 1959). Water colour, ammonia, and nitrate-nitrogen were measured using reagents and standards marketed by the W. A. Taylor Company, Baltimore, Maryland. A Beckman $\mathrm{pH}$ meter, Model 72 , was used to determine $\mathrm{pH}$; temperature was measured with a mercury thermometer; total of solids was determined by measuring the loss in weight of a $500 \mathrm{ml}$. sample dried at $110^{\circ} \mathrm{C}$.

Inuvik is surrounded by twelve bodies of water varying from small ponds to relatively large and deep lakes (Fig. I). All of these lakes and ponds have some general chemical properties in common. The results of chemical studies of 8 of them, and the Mackenzie River, are given in Table I. All were exceptionally low in sodium chloride in contrast to many of the lakes of the Alaskan Arctic slope (Boyd and Boyd 1959). The lakes of the Inuvik area with the exception of Shell Lake varied from moderate hardness to excessive hardness. The Mackenzie River was characterized by high concentrations of calcium and magnesium ions. As might be expected, Hidden Lake and the river are similar to one another in chemical composition; from late October to May each year a great deal of river water is pumped into the lake to insure the town's water supply. The generalization can be made that waters of this area are hard; the analyses reported herein agree well with those for other parts of the Mackenzie River (Thomas I 957).

In all but one case, Duck Lake, the phenolphthalein alkalinity was zero (Table I). Therefore, alkalinity was not a function of hydroxide and 
TABLE I. Chemical and microbial properties of selected Lakes and the Mackenzie River.

\begin{tabular}{|c|c|c|c|c|c|c|c|c|c|}
\hline & $\begin{array}{c}\text { Dolomite } \\
\text { Lake }\end{array}$ & $\begin{array}{l}\text { Shell } \\
\text { Lake }\end{array}$ & $\begin{array}{c}\text { Gravel Pit } \\
\text { Lake }\end{array}$ & $\begin{array}{c}\text { Hospital } \\
\text { Lake }\end{array}$ & $\begin{array}{l}\text { Duck } \\
\text { Lake }\end{array}$ & $\begin{array}{l}\text { Twin } \\
\text { Lake }\end{array}$ & $\begin{array}{l}\text { Boot } \\
\text { Lake }\end{array}$ & $\begin{array}{c}\text { Mackenzie } \\
\text { River }\end{array}$ & $\begin{array}{c}\text { Hidden } \\
\text { Lake }\end{array}$ \\
\hline Depth (feet) & $>35$ & I 2 & 12 & 6 & 9 & $7^{-10}$ & 6 tor $5-r 7$ & I $5-20$ & $5^{2}$ \\
\hline Color & 40 & 60 & 30 & 35 & 25 & 20 & 100 & 20 & 30 \\
\hline \multirow[t]{2}{*}{ Potability } & + & + & + & + & - & - & + & + & + \\
\hline & \multicolumn{9}{|c|}{ PARTS PER MILLION } \\
\hline $\mathrm{NaCl}$ & 20.2 & 6.5 & 12.0 & 10.0 & $2 \mathrm{I} .8$ & I 9.9 & 8.1 & I 6.2 & 22. I \\
\hline Total Hard. & I Or.o & 35.8 & 370.8 & 755.6 & I 07.6 & 218.4 & 76.3 & I 09.8 & I 04.6 \\
\hline Ca Hard. & 72.0 & 22.2 & 240.2 & 531.6 & 69.8 & I $59 \cdot 4$ & 46.7 & $7^{6.8}$ & $74 \cdot 4$ \\
\hline Mg Hard. & 29.0 & I 3.6 & 1 30.6 & 224.0 & 37.8 & 59.0 & r 9.6 & 33.0 & $3^{0.2}$ \\
\hline P. Alk. & o & o & o & 0 & 9.0 & o & o & o & 0 \\
\hline M. Alk. & 84.6 & 25 & $5^{2.9}$ & 88.4 & 66.8 & 105.9 & 31.6 & 90.2 & $74 \cdot 5$ \\
\hline $\mathrm{pH}$ & 6.9 & 6.7 & 6.9 & 6.7 & 6.9 & 6.9 & 6.7 & 6.8 & 6.0 \\
\hline Iron & o' & 0.1 & o & o & o & 0 & o.I & o & 0 \\
\hline $\mathrm{NH}_{3}-\mathrm{N}$ & o & O.I & 5 & $\mathbf{I}$ & 2 & $\mathbf{o}$ & $\mathbf{I}$ & I & o \\
\hline $\mathrm{NO}_{3}-\mathrm{N}$ & 0 & o & o & I & 2 & o & 0 & 0.5 & 0 \\
\hline \multirow[t]{2}{*}{ Temp., ${ }^{\circ} \mathrm{C}}$. & 14 & 15 & 14 & I 2.5 & 14.8 & I 3.5 & I $4 \cdot$ I & 15.0 & I6.o \\
\hline & \multicolumn{9}{|c|}{ MICROORGANISMS PER ML. } \\
\hline Nutrient agar, $55^{\circ} \mathrm{C}$. & 0 & o & 0 & o & I & 2 & I & 1 & o \\
\hline Nutrient agar, $37^{\circ} \mathrm{C}$. & IO & 220 & 60 & 49 & 5 & 18 & $2 \mathrm{I}$ & 8 & 49 \\
\hline Nutrient agar, $22^{\circ} \mathrm{C}$. & 99 & 300 & 170 & 290 & I6o & 700 & 250 & 59 & 300 \\
\hline Nutrient agar, $2^{\circ} \mathrm{C}$. & 65 & 290 & $8_{5}$ & I IO & 83 & 93 & 60 & 34 & 240 \\
\hline Sabouraud's agar, $22^{\circ} \mathrm{C}$. & 1 & o & o & o & 0 & 3 & 3 & $\mathrm{I}$ & o \\
\hline Thornton's agar, $22^{\circ} \mathrm{C}$. & 65 & 400 & 85 & 120 & 53 & 310 & 65 & 35 & 280 \\
\hline Date ( 1964$)$ & Aug I & Aug I & Aug I & Aug 3 & Aug 3 & Aug 4 & Aug 4 & Aug 4 & Aug 7 \\
\hline
\end{tabular}




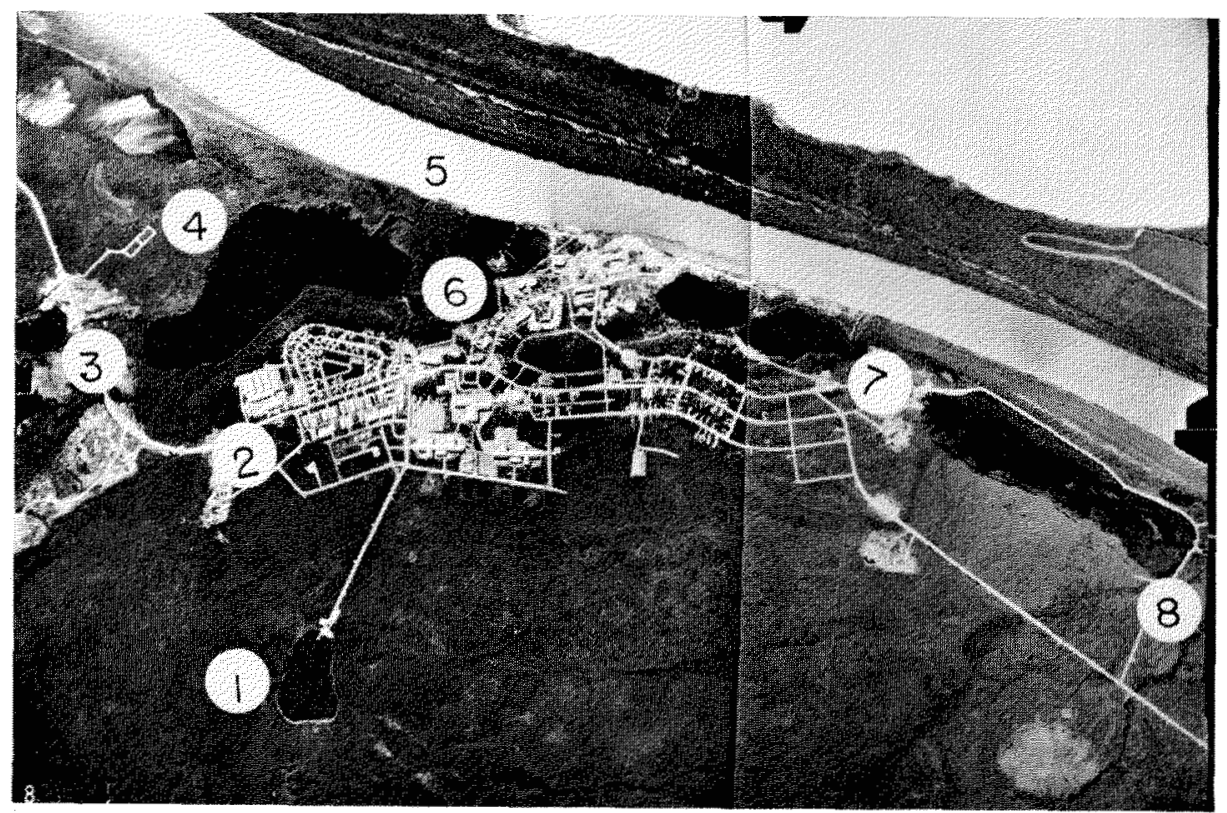

FIG. I. Photo-map of water sources sampled at Inuvik, Northwest Territories, Canada. I. Hidden Lake; 2. Hospital Pond; 3. Gravel Pit Lake; 4. Boot Lake; 5. Mackenzie River; 6. Duck Lake; 7. Twin Lake; 8. Sewage Lagoon. Two other lakes (Shell and Dolomite Lakes) sampled between the airport and town are not shown. Maps reprinted from Royal Canadian Air Force photos VRR 2099/4, 808, and 809 with the kind permission of Defence Photographic Interpretation Centre, R.C.A.F. Station Rockcliffe, Ottawa 7, Ontario, Canada.)

carbonate ions; primarily, the total alkalinity was a result of bicarbonates. The nitrate-nitrogen and ammonia-nitrogen concentration varied from lake to lake, with some showing significant amounts, while other lakes had little or no detectable nitrogen. Although the bacterial counts varied, the number of thermophilic bacteria and molds were consistently very low.

\section{GHANGES IN CHEMICAL COMPOSITION AND NUMBER OF BACTERIA}

In 1964 , the annual break-up occurred shortly after 7 June. By the time this study was initiated on 25 June there was no evidence of ice in the Mackenzie River or in any of the lakes or ponds. The turbidity of the river was at its maximum, ranging from 187 p.p.m. on 6 July to a low of $3^{2}$ p.p.m. on 4 August. Except for Twin Lake, the chemical composition of the various bodies of water showed but slight variation during July (Fig. 2). The total hardness as well as other chemical constituents of Twin Lake almost doubled that month. The variation was possibly caused by reduced runoff along with a high degree of evaporation resulting in concentration of the minerals. Although this lake is connected to the Mackenzie River by a narrow channel, inflow of river water was almost nil. Boot Lake, also connected to the river by a narrow channel actually showed a slight decrease in mineral concentration in mid-July, probably a result of rain 


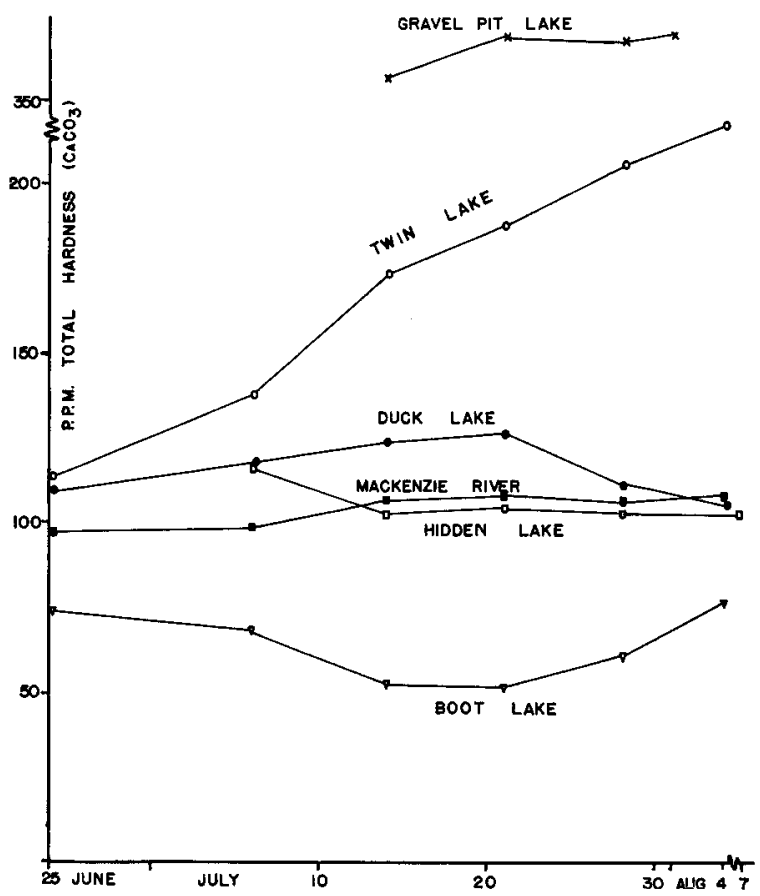

FIG. 2. Seasonal changes in total hardness of lakes of the Inuvik area.

and dilution by runoff, the latter being more extensive here than around Twin Lake.

In contrast to the chemical composition, the bacterial counts during that period showed significant variation. For the two lakes with channels leading into the river (Boot and Twin Lakes), the bacterial pattern was similar (Fig. 3). Counts on nutrient agar incubated at $22^{\circ} \mathrm{C}$. reached a maximum number on 14 July after a drop in number from the first samples which were taken on 25 June; these high initial counts were probably a result of runoff. Counts of thermophilic bacteria were low as were counts of molds. The highest number of thermophilic bacteria was observed on 25 June when the Mackenzie River had a count of 7 per ml. Counts of mesophilic

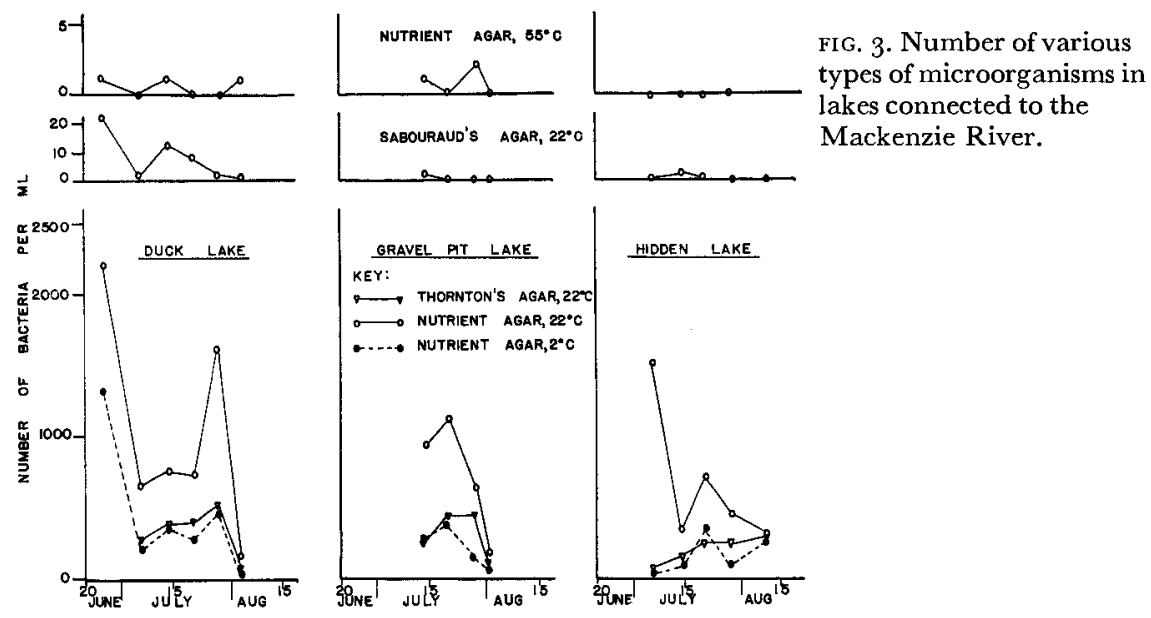


bacteria on media incubated at $37^{\circ} \mathrm{C}$. were low, ranging between o and 57 for the above three bodies of water. Little difference was noted between the counts on nutrient agar incubated at $2^{\circ} \mathrm{C}$. and on Thornton's standardized medium incubated at $22^{\circ} \mathrm{C}$. except on I4 July when a peak psychrophilic bacteria population was observed. However, the maximum number of psychrophilic bacteria was about half the number of mesophilic types. Counts on Thornton's medium showed a slight increase during this period.

The same general bacterial changes reported for river-connected lakes were observed on three lakes not directly connected to the river (Fig. 4), although the time periods of high and low counts were markedly different. Duck Lake reached a peak population two weeks after Twin and Boot Lakes, while Hidden Lake and Gravel Pit Lake had maximum numbers on 21 July.

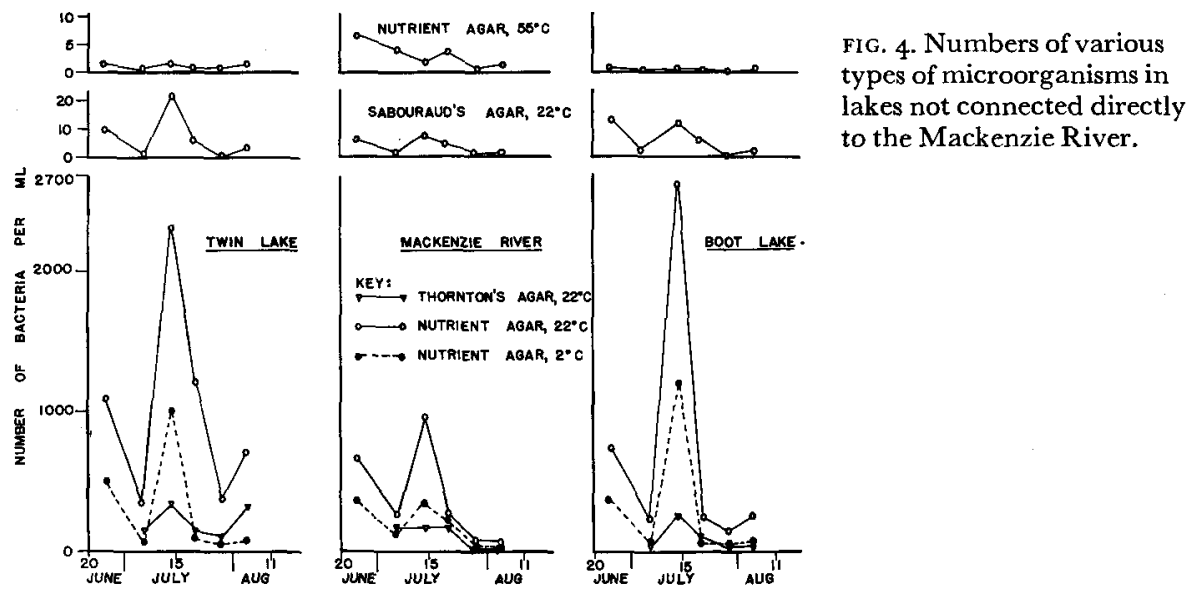

Except for Duck and Gravel Pit Lakes, the bacterial counts at $37^{\circ} \mathrm{C}$. like those for molds and thermophilic microbes were quite low, usually averaging less than $5^{\circ}$ per $\mathrm{ml}$. Duck Lake had a high of $\mathrm{I} 30$ bacteria per ml. on I 4 July and I 90 per ml. on 28 July, and Gravel Pit Lake contained 160 bacteria per ml. on 2 I July (Fig. 5). All samples were subjected to standard potability tests (A.P.H.A. I 960 ) using five $10 \mathrm{ml}$. samples in lactose broth for each body of water. The lakes and the river were usually potable, but coliform bacteria were present in a few instances; positive tests for coliform bacteria were observed for Hidden Lake on 6 July, the river on 2 I July, the river and Twin Lake on 28 July, Duck Lake on 3 August, and Twin Lake again on 4 August. There were two possible sources of the coliform bacteria from these bodies of water. Ravens nested near Hidden Lake, particularly on top of and near the pump house for the town's water supply and were the probable source of contamination in this instance because human access to Hidden Lake is limited by a locked gate. The other areas that at times showed contamination were in regions where ravens and especially people had ready access to the water. Near Twin and Duck Lakes a number of families lived in tents or modified tents and had no serviced water supply 


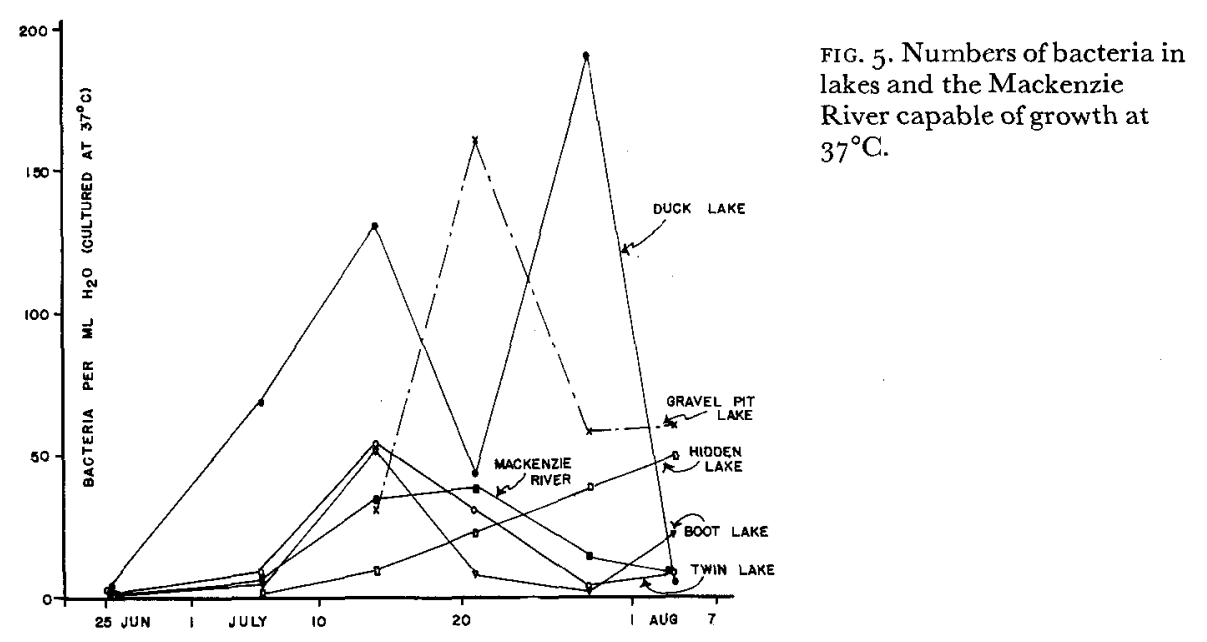

or sewage disposal system. There is little doubt that some sewage found its way into these lakes and could be detected for a short time afterwards. For most of the summer, however, the water in this area was potable.

Very few molds were detected (Figs. 3 and 4 ). For all but one lake maximum numbers of molds were counted on I 4 July, 8 per ml. for the river, 22 per $\mathrm{ml}$. for Twin Lake, I I per $\mathrm{ml}$. for Boot Lake and i per $\mathrm{ml}$. for both Gravel Pit and Hidden Lakes; Duck Lake had its maximum mold count of $2 \mathrm{I}$ per ml. on 25 June.

Psychrophilic bacteria ranged from 2.8 to 8 I.3 per cent of mesophilic forms (Figs. 3 and 4 ). Maximal counts of psychrophilic microbes were generally observed on the same days as the maximal counts of mesophilic forms.

Bacterial counts on Thornton's standardized medium were almost always lower than those on nutrient agar, usually between 2.7 and 93.3 per cent of the nutrient agar growth at $22^{\circ} \mathrm{C}$., and approximated the numbers observed on nutrient agar incubated at $2^{\circ} \mathrm{C}$. Except for Hidden Lake and Gravel Pit Lake, bacterial highs on Thornton's medium and the other medium occurred on the same date.

\section{RUNOFF WATER}

Inuvik and adjacent regions are low compared to the surrounding terrain, thus during most of the summer, Inuvik receives some drainage from higher areas. All runoff is at the ground surface because of the underlay of continuous permafrost. The contour of the land has set up natural drainage routes, and roads have been built with this in mind; where roads cross, culverts are used to prevent them from washing away and to provide drainage with a minimum of disturbance to the permafrost. A gravel road built upon bedrock runs from the town to the airport six miles away. It crosses a number of culverts which allow runoff from drainage areas to proceed to either lakes or the Mackenzie River. 
In order to learn something of the effect of runoff on the various bodies of water of this region, runoff samples were collected on 2 August, shortly after rain. (On 30 July, 0.25 inches fell to make a monthly total for July of 3.00 inches). Starting at the airport and adjacent Dolomite Lake (8.5 miles southeast of the town), samples were collected at nearly all of the culverts on the way into town. The chemical composition of the runoff water varied (Table 2). Near the airport the water was hardest, particularly water draining into Dolomite Lake; the total hardness and other mineral constituents gradually decreased as the town was approached. The water became hard again in the culvert directly south of the hospital; water from this culvert eventually ran into Boot Lake. However, other softer runoff drained into the Lake and it is this water that reduced its mineral composition (Fig. 2). The area drained by the hospital culvert is extensive, apparently extending back into the hills for five to six miles. Two major drainage areas were in town; one of these, next to the theatre, drained from an area with low pockets and isolated pools. The high mineral content of the pools was a result of isolation and evaporation taking place between rainfalls. Sufficient rain, of course, moved the water level up to where drainage could occur.

Bacteria and other microorganisms including bluegreen and green algae, protozoa, rotifers, and tartegrades were present in all of the runoff samples. No thermophilic bacteria were detected. The number of bacteria capable of growth at $37^{\circ} \mathrm{C}$. varied, but was highest in the runoff samples

TABLE 2. Chemical and microbial properties of runoff water.

\begin{tabular}{|c|c|c|c|c|c|c|c|c|}
\hline & $\begin{array}{c}\text { Dolomite } \\
\text { Lake }\end{array}$ & Airport & $\begin{array}{c}\text { Hidden } \\
\text { Lake }\end{array}$ & $\begin{array}{c}\text { Hospital } \\
\text { Pond }\end{array}$ & $\begin{array}{c}\text { Gravel } \\
\text { Pit Lake }\end{array}$ & Hospital & Church & Theatre \\
\hline COLOR & $6_{5}$ & I $5^{\circ}$ & 140 & 195 & I IO & $6_{5}$ & go & 70 \\
\hline POTABILITY & + & + & + & + & + & + & + & + \\
\hline & \multicolumn{8}{|c|}{ PARTS PER MILLION } \\
\hline $\mathrm{NaCl}$ & I 4.2 & 10.0 & 8.2 & I I 6 & I 0.0 & 16.4 & 8.4 & I 6.8 \\
\hline Total Hard. & 279.2 & 87.8 & 21.8 & 28.2 & 26.2 & I008.0 & 87.2 & I $55^{2.4}$ \\
\hline Ca Hard. & I 88.0 & 64.0 & 12.0 & I. 9.2 & I 4.2 & 709.6 & 60.8 & 1024.4 \\
\hline Mg Hard. & $9 \mathrm{I} .2$ & 23.8 & 9.8 & 9.0 & 12.0 & $299 \cdot 4$ & 26.4 & 528.0 \\
\hline P. Alk. & 0 & o & o & o & 0 & 8.0 & 0 & 4.4 \\
\hline M. Alk. & I 99.4 & 87.6 & I6.2 & I 9.8 & I 6.2 & 208.4 & 27.2 & 372.4 \\
\hline $\mathrm{pH}$ & 7.1 & 6.9 & 6.8 & 6.7 & 6.8 & 6.7 & 7.9 & 7.0 \\
\hline Iron & 0 & 0 & 1.0 & 0.5 & I.o & $\mathbf{o}$ & I.o & 0 \\
\hline $\mathrm{NH}_{3}-\mathrm{N}$ & I & 5 & 10 & I 5 & 2 & 2 & 2 & o \\
\hline $\mathrm{NO}_{3}-\mathrm{N}$ & o & o & 0.5 & 0.5 & 1 & $\mathbf{I}$ & 2 & 3 \\
\hline \multirow[t]{2}{*}{ Temp. ${ }^{\circ} \mathrm{C}$. } & $9 \cdot 4$ & 7.8 & $9 \cdot 6$ & 4.9 & 10.0 & $7 \cdot 0$ & I 0.0 & I 0.0 \\
\hline & \multicolumn{8}{|c|}{ MICROBES PER ML. } \\
\hline Nutrient agar, $55^{\circ} \mathrm{C}$. & $o$ & o & $o$ & o & o & o & 0 & 0 \\
\hline Nutrient agar, $37^{\circ} \mathrm{C}$. & 3 & I & 9 & 13 & 6 & 79 & 16 & 210 \\
\hline Nutrient agar, $22^{\circ} \mathrm{C}$. & 280 & $45^{\circ}$ & 940 & 120 & 1200 & I goo & 1200 & 2100 \\
\hline Nutrient agar, $2^{\circ} \mathrm{C}$. & 89 & 100 & 230 & $5^{6}$ & 170 & 300 & 210 & 430 \\
\hline Sabouraud's agar, $22^{\circ} \mathrm{C}$. & 0 & 0 & I & 0 & I & 29 & I & 10 \\
\hline Thornton's agar, $22^{\circ} \mathrm{C}$. & 140 & 200 & 460 & I IO & 540 & $45^{\circ}$ & $34^{\circ}$ & $53^{\circ}$ \\
\hline
\end{tabular}


collected in the town proper. When other media and incubation temperatures were used, a few samples taken away from the town showed high counts, but generally highest bacterial counts were obtained in the town itself. Except for the drainage near the hospital and theatre, the number of molds was low. The counts on Thornton's medium were significantly higher than counts on nutrient agar incubated at $2^{\circ} \mathrm{C}$.

Like many other regions of the far North, Inuvik can be classified as a desert since the annual precipitation is approximately io inches in terms of water equivalent, approximately one-third of which is rain (Pihlainen I 962; MacKay 1963). The rain and snow may dilute the lakes and rivers directly, or the precipitation may fall upon drainage areas and pick up mineral and living and non-living organic matter before running off into the larger bodies of water. All of these factors coupled with evaporation have a profound effect on the chemical and biological activities of these waters.

\section{WATER SUPPLY PROBLEMS}

One of the determining factors in relocating Aklavik at the site called East Three (Inuvik) was a good and readily available source of water. There are a number of different lakes in the region in addition to the Mackenzie River (Fig. I), many of which are deep enough for year-round use. The Mackenzie River was chosen as the major source of water for the townsite; however, it is not used directly. Instead, Hidden Lake, located above the town, was selected as a reservoir. The procedure generally used for water storage is as follows. As soon as the ice on the Mackenzie River is thick enough to support the weight of a caterpillar tractor (usually late October or early November) a pumping station is established on the river ice. From October to May a 4-inch line laid below the ice carries water into Hidden Lake at a rate of 150 gallons per minute. During the summer, the lake serves as the only water source. Hidden Lake is of oval shape, deep (50 to $5^{2}$ feet) near the pumping station, and shallow (less than 5 feet) near the centre. When the population of Inuvik is at a maximum during the summer, 1.25 million gallons of water are used daily. Some suspended matter settles out of water stored in the reservoir leaving a less turbid product than the original river water.

The first step in the purification of Hidden Lake water is a screening process to rid it of suspended matter. Water is passed through a Micro Strainer (manufactured by Glenfield and Kennedy Ltd, I05 Park Street, London W. I). The screen size is Mark 'o' of approximately 20 microns per aperture and $\mathrm{i} 60,000$ per sq. inch. While this size will strain or filter out suspended matter, most bacteria are below these size dimensions and pass through the filter. After filtration, lake water is treated with chloride gas or hypochlorite by allowing it to flow through an automatic chlorinator ('Chlorinizer' manufactured by BIF Industries of Canada, Limited, Toronto) metred to deliver between 2-3 p.p.m. residual chlorine. The 


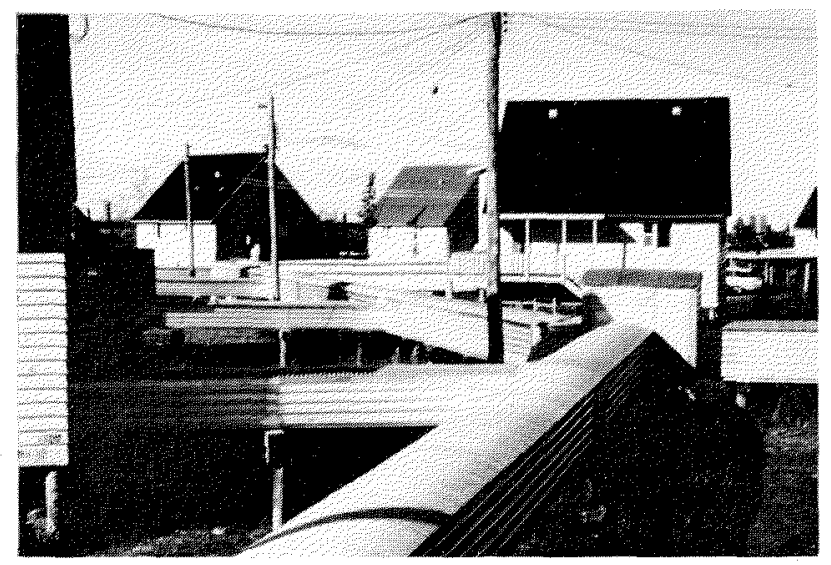

FIG. 6. Utilitor system constructed on pilings to minimize any disturbance of permafrost.

chlorine treatment is effective in destroying almost all microorganisms in the filtered lake water, for bacterial counts at the pump house showed a marked reduction from the untreated water (Table 3 ).

Water is distributed throughout the serviced part of the town by heated pipelines which are housed in insulated utilitors that have been raised above ground on pilings (Fig. 6). Utilitors originate at Hidden Lake and carry heated water for utility and drinking purposes about the town by gravity flow. All houses and buildings on the utilitor system have the standard, conventional plumbing found in temperate regions. The heated pipelines serve two purposes: they prevent water from freezing and carry live steam for heating houses and other buildings, making a town without chimneys. A heated, above ground system is necessary for the year-round use of water in arctic and subarctic regions; water and sewage lines cannot be buried undergound because of continuous permafrost. Like any other system, this one has its own unique problems. Dead ends, where the flushing actions of the circulation system are minimized, result in high bacterial numbers (Table 3). Even the 'cold water' mains of this system are heated, and if any organic or usable inorganic matter has accumulated, significant growth of bacteria can and does take place. In some cases large numbers of mesophilic bacteria were found but no thermophilic bacteria developed, and very few psychrophilic forms were found. It appears that the cold water system of this town can harbour significant numbers of bacteria. The ratio of psychrophilic to mesophilic bacteria was much lower than found in natural waters and tended to confirm the suggestion that a unique flora exists within this system.

The personnel of the Northern Canada Power Commission periodically 'bleed' and flush 'dead-ended' areas and increase the chlorine concentration so that a residual of 3 p.p.m. chlorine is maintained everywhere in the lines in an attempt to reduce the high bacterial counts. Such a procedure was carried on in the middle of August a few days before this project was terminated so its efficacy could not be checked. As an alternative the use of the more stable chloramine is now being considered. 
TABLE 3. Microbial counts from water collected from selected dwellings.

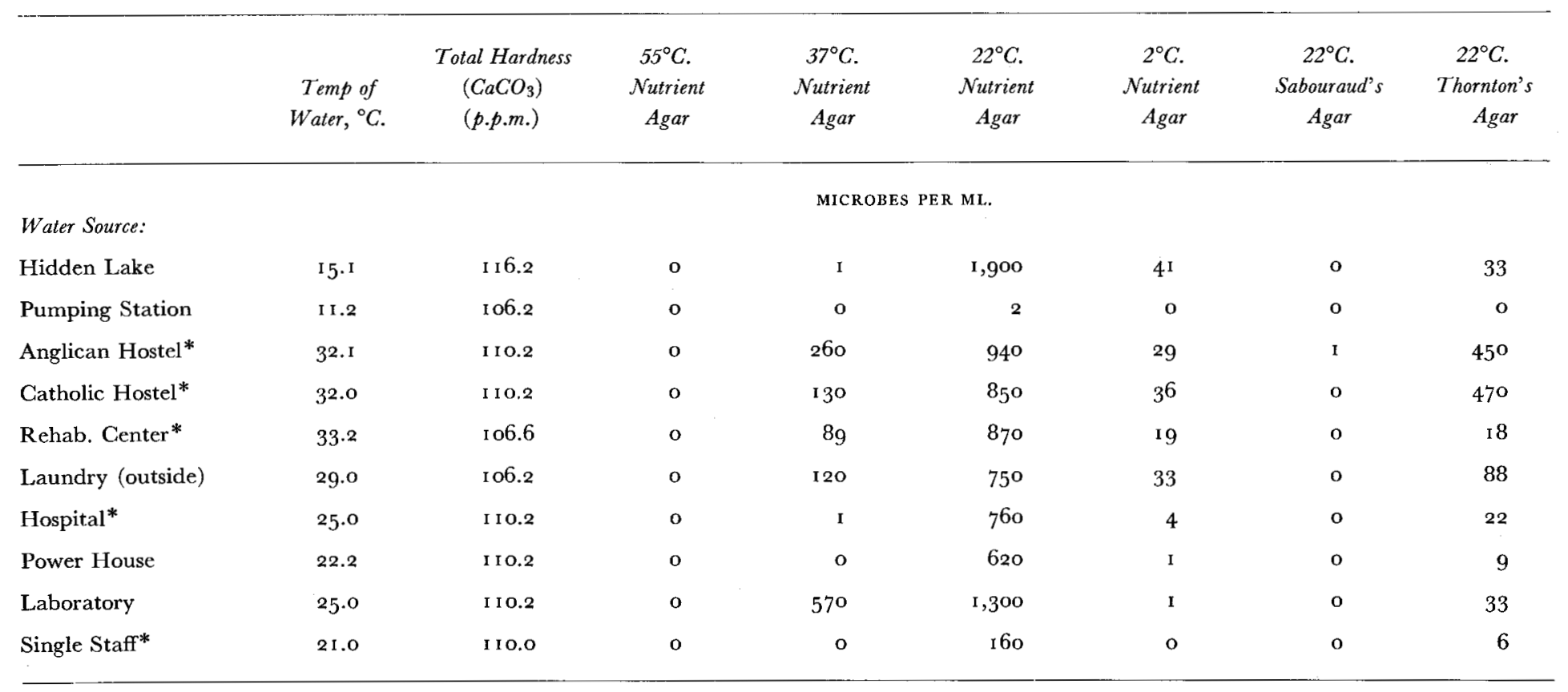


Only that part of Inuvik housing government workers or carrying out direct government services is on the utilitor system. The rest of the town is unserviced and relies on three service centres. Each centre contains a receptacle for sewage and a water tap. Periodically the water tanks are filled and sewage is removed, but less attention is given to this system than the one used in the serviced part of town. Although potable water was present in all of the service centres, bacterial counts were extremely high (Table 4 ). These data emphasize the need for frequent cleaning and attention to units of this type, and for bacteriological controls which can be carried out and interpreted by local qualified personnel, instead of having to rely on far distant laboratories. However, in spite of its shortcomings, this system is one of the best operated in the North American Arctic where most systems are rather primitive (Boyd and Boyd 1965 ).

TABLE 4 . Microorganisms present in water from utility stations.

\begin{tabular}{lrrr}
\hline & $U T-I$ & $U T-2$ & $U T-3$ \\
Temperature & 22.2 & 17.5 & 24.2 \\
Potability & + & + & + \\
& & Microbes per ml. & \\
\cline { 2 - 4 } Nutrient agar, $55^{\circ} \mathrm{C}$. & 0 & 0 & 0 \\
Nutrient agar, $37^{\circ} \mathrm{C}$. & 7,300 & 3,800 & 130 \\
Nutrient agar, $22^{\circ} \mathrm{C}$. & 16,000 & 24,000 & 3,100 \\
Nutrient agar, $2{ }^{\circ} \mathrm{C}$. & 1,300 & 150 & 21 \\
Sabouraud's agar, $222^{\circ} \mathrm{C}$. & 0 & 1 & 0 \\
Thornton's agar, $22^{\circ} \mathrm{C}$. & 1,800 & 600 & 870 \\
\hline
\end{tabular}

One of the most difficult problems of the North, especially in inland regions, is sewage disposal. Although many methods have been tried, a great deal of research is needed on equipment design and on the possible use of low temperature microbial metabolism for sewage treatment. One system which has been used to a limited extent and which shows promise is the sewage lagoon or oxidation pond. It consists of a very shallow lagoon where oxygen can diffuse into the surface layers and be utilized in the aerobic breakdown of organic matter, and where anaerobic processes will be non-existent or minimized. In the Alaskan Arctic at Fort Yukon, a pond is now being used on a seasonal basis (Anderegg et al. I 960). Effluent from a school accumulates during the winter when the lagoon is covered with ice, and oxidation does not take place until the following summer when the ice melts. An advantage of this particular system is that school is in recess when oxidation takes place so no additional accumulation occurs during the summer.

The system used at Inuvik is partially oxidation in a restricted reservoir and partially dilution. The oxidation pond for the town was originally a drainage area formed by some nearby hills. The pond itself is approximately 2 to 2.5 feet deep at the end nearest town, and has been artificially deepened 
to 7 feet at the far end; at this end is a weir which, although closed in summer, allows some overflow. Oxidation proceeds throughout the summer. When a thin crust of ice forms on the lagoon in the fall, the gates of the weir are opened, and sewage drains into the Mackenzie River during the period of ice cover. Diluted sewage is carried out until the spring ice break-up in May when the gates of the weir are again closed. Runoff water dilutes any remaining sewage, and warmer weather coupled with continuous sunlight makes for the increased biological activity necessary for a practical oxidation pond.

The limited study presented (Table 5) indicates that the chemical composition of the sewage lagoon is somewhere near that of Hidden Lake with the exceptions of high $\mathrm{pH}$, a detectable phenolphthalein alkalinity, and considerably more iron; also, its colour was enhanced by the presence of sewage.

The number of microorganisms in the sewage lagoon afforded a flora which differed markedly from the rest of the lakes. The number of thermophilic bacteria was the highest, due no doubt, almost entirely to forms indigenous to the intestinal tract of man. The number of coliform bacteria present in domestic sewage is about I00,00o or more per ml. (Rudolfs no date). In the Inuvik lagoon, the number of microorganisms capable of growth at $37^{\circ} \mathrm{C}$. was half this number while the number of coliform bacteria was about 20 per cent of this total or about 20,000 per ml. According to

TABLE 5. Microbial and chemical properties of the sewage lagoon.

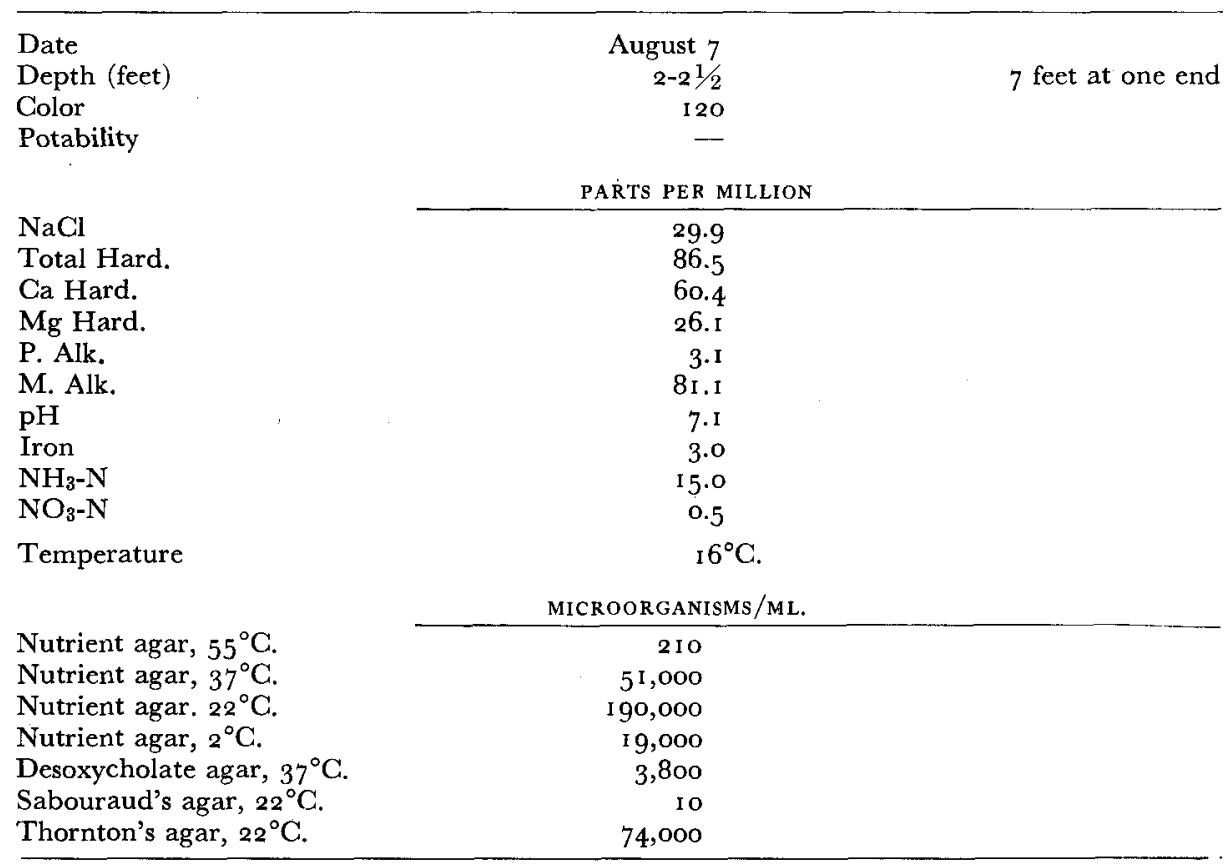


Steel (I 953) a good pond may be as efficient as a trickling filter and reduce the number of coliform bacteria from 100,000 to 50 per $\mathrm{ml}$. Obviously the pond at Inuvik is not nearly as efficient as one in temperate regions. Steel also states that coliform bacteria are enumerated as an index of the efficiency of the system for removing pathogens, but it is difficult to evaluate the Inuvik oxidation pond since our studies were not carried out over the entire summer. The values of 0.5 p.p.m. for $\mathrm{NO}_{3}-\mathrm{N}$ and I 5 p.p.m. for $\mathrm{NH}_{3}-\mathrm{N}$ found in the lagoon water are in the range of the values cited for normal raw sewage (Steel I 953) which would indicate a low rate of oxidation. The lagoon had little odour and a substantial amount of algae growing near its outfall. Future study of the area should cover the entire period that the sewage lagoon is operational.

\section{REFERENCES}

ALlen, o. N., I95I. Experiments in soil bacteriology. Minneapolis, Minn. Burgess Publishing Company, I $7 \mathrm{pp}$.

ANDEREgG, J. A., C. F. WALTERS, D. HILlARD and H. F. MEYERS, I g6o. Sewage lagoons in Alaska. Science in Alaska, I959, A.A.A.S., College, Alaska, pp. 45-46.

AMERICAN PUblic HEALTh Association, i 960 . Standard methods for the examination of water and sewage, I I th ed. New York, 626 pp.

BAIRD, IRENE, I 96o. Inuvik, place of man. Beaver Outfit, 291 : I6-23.

BOYD, W. I., I 959. Limnology of selected arctic lakes in relation to water supply problems. Ecology, 40: 49-54.

and J. W. BOYD, 1959. Water supply problems at Point Barrow. Journal of the American Water Works Association, 5 I : 89o-g6.

1963. A bacteriological study of an arctic coastal lake. Ecology, 44:705-1 o.

- 1965 . Water supply and sewage disposal developments in the far North. Fournal of the American Water Works Association, 57:858-68.

BRown, R. J., I 960 . The distribution of permafrost and its relation to air temperature in Canada and the U.S.S.R. Artic, 13:163-77.

maGkaY, J. R., r963. The Mackenzie Delta area, N.W.T., Department of Mines and Technical Surveys, Geographical Branch Memoir 8, 202 pp.

MerRiLl, G. L., J. A. PIHLAINEN and R. F. LEGGetT, i 96o. The new Aklavik: search for the site. Engineering Journal, 43: 52-57.

Pihlainen, J. A., I962. Inuvik, N.W.T. Engineering site information. National Research Council of Canada. Division of Building Research. Technical Paper 135, 18 pp.

RUdolfs, w., no date. Principles of sewage treatment, National Lime Association Bulletin, No. 212, Washington, D.C.

STEEL, E. W., 1 953. Water supply and sewage, New York: McGraw-Hill, p. $5^{82}$.

тномаs, J. F. J., I957. Industrial water resources of Canada. Mackenzie River and Yukon River drainage basins in Canada, 1952-53, Water Survey Report, No. 8, Ottawa: Queens Printer, $7^{8} \mathrm{pp}$. 